\title{
Effect of Accounting Flexibility on Earnings Management through Stock Repurchases
}

\author{
Randall Zhaohui $\mathrm{Xu}^{1} \&$ Yi Yang ${ }^{2}$ \\ ${ }^{1}$ School of Business, University of Houston-Clear Lake, USA \\ ${ }^{2}$ Xiamen Bank, China \\ Correspondence: Yi Yang, Xiamen Bank, 101 North Hubin Road, Xiamen, Fujian, 361012, China. Tel: \\ 86-592-539-2652. E-mail: yangyi1@xmbankonline.com
}

Received: July 26, 2013

Accepted: August 6, 2013

Online Published: September 23, 2013

doi:10.5539/ibr.v6n10p40

URL: http://dx.doi.org/10.5539/ibr.v6n10p40

\begin{abstract}
Prior research (Taylor \& Xu, 2012) finds that firms that attempt to increase EPS to meet analyst forecasts through stock repurchases give up the opportunity to time their buybacks to benefit from temporary undervaluation of their stock as is the case for firms that repurchase stock for other purposes. The current study explores a possible explanation for the costly behavior by investigating whether firms with constraints in their ability to inflate accruals are more likely to use stock repurchases as a means to manage earnings. The research question is tested using a logit regression model with quarterly data from 1992 to 2009, controlling for various previously documented factors that affect stock repurchases and/or earnings management. The empirical test results are consistent with the hypothesis that firms with lower accounting flexibility are more likely to manage earnings through stock repurchases. The study contributes to the earnings management literature by documenting the substitution effect of alternative means of earnings management.
\end{abstract}

Keywords: accounting flexibility, stock repurchases, real earnings management

\section{Introduction}

Prior research finds firms to manage earnings by manipulating accruals (accrual earnings management) and/or operating activities (real earnings management). Extant literature documents various forms of real earnings management activities. Specifically, firms are found to increase reported earnings per share (EPS) to meet earnings targets via open market stock repurchases (Bens, Nagar, \& Wong, 2003; Hribar, Jenkins, \& Johnson, 2006).

Taylor and Xu (2012) find that firms that attempt to increase EPS through stock repurchases pay a relatively higher price for their stock than firms that repurchase stock for other reasons, such as repurchasing in order to take advantage of temporary undervaluation of their stock. Specifically, when firms use stock repurchases as a means of inflating current period earnings, they would have to give up the opportunity to time their stock buybacks when they believe that the stock price is lower than the firms' intrinsic value. In other words, firms may buy back shares even if stock price is high relative to the true value. Given the documented costs with real earnings management, one might wonder why firms would choose to engage in real earnings management activities. The current study attempts to explore a possible explanation for the question, i.e., whether firms with constraints in their ability to inflate accruals have a higher propensity to use stock repurchases as a tool to manage earnings?

The issue relates to the choice faced by firms that attempt to increase their EPS to meet analyst forecasts. Since accruals management does not consume cash, it is less costly and presumably preferable to manipulation of the underlying business activities, such as stock repurchases (Black et al., 1998). However, when managers face constraints in their ability to inflate accruals, accruals management becomes more difficult and has higher risks of regulatory scrutiny and shareholder lawsuits, and incentives for real earnings management increase (Demski, 2004; Ewert \& Wagenhofer, 2005). Consequently, firms that have constraints in their ability to increase EPS via accruals manipulation are more likely to choose to increase EPS through stock repurchases.

The above argument is also consistent with empirical findings. Barton and Simko (2002) show that there are limits to the extent firms could inflate accruals and firms with high level of constraints on accruals management are less likely to manage earnings by accruals. Wang and D'Souza (2006) document that firms with low accounting flexibility are more likely to cut R\&D expenditures. Cohen, Dey, and Lys (2008) find that firms are more likely to 
manage earnings by manipulating real business activities rather than accruals in the post-Sarbanes Oxley era, possibly due to the heightened regulatory scrutiny on financial reporting.

In the current study, the level of constraints on accruals management in the current period is measured by abnormal total net operating assets over sales ratio (AbNOA), which serves as aproxy for the extent to which net operating assets is overstated compared to a neutral application of GAAP. Following Hribar et al. (2006), firms that meet or just beat analyst earnings forecasts and would have missed analyst forecasts without stock repurchases are assumed to be engaged in real earnings management through stock repurchases.

We investigate the association between accounting flexibility and firms' propensity to manage earnings by accruals and by real business activities with a logit model. The empirical test results are consistent with the hypothesis. Firms with high AbNOA (constraints in their ability to inflate accruals) are found to be more likely to engage in earnings management through stock repurchases.

The current study contributes to the earnings management literature by providing more evidence on the trade-off between alternative means of earnings management. Wang and D'Souza (2008) find that firms with low accounting flexibility tend to cut $R \& D$ expenses to improve earnings. The results of the current study complement those of Wang and D'Souza (2008). Using the stock repurchase setting, the study shows that constraints on firms' ability to inflate accruals induce firms to engage in earnings management through costly real business transactions. The findings suggest a substitution effect between the accruals and real earnings management activities based on the costs of the alternative forms of earnings manipulations.

The remainder of this paper is organized as follows. Section 2 reviews relevant literature and develops hypotheses. Section 3 describes the sample and research methodology. Section 4 presents test results. Section 5 concludes the paper.

\section{Review of Literature and Development of Hypotheses}

\subsection{Review of Prior Earnings Management Literature}

Reported earnings are subject to accruals management and real earnings management. Accruals management refers to exploiting the accounting discretion in GAAP, including alternative accounting choices (LIFO vs. FIFO, straight-line vs. accelerated depreciation, among others) and managerial judgment and estimates (on such items as loss reserves and expected life of assets). Real earnings management is achieved by opportunistically altering the firm's underlying business activities. Firms are found to inflate earnings by reducing R\&D and advertising expenditures and adjusting product price and credit policy (Bushee, 1998; Roychowdhury, 2006).

\subsection{Research Hypotheses-Relation between Propensity of Earnings Management through Stock Repurchases and Constraints in Firms' Ability to Inflate Accruals}

Both accruals earnings management and real earnings management have costs associated with them. Since real earnings management, such as stock repurchases, involves real business transactions and cash flows, it is presumably more costly than accruals management that does not affect the underlying business activities. Black, Sellers, and Manly (1998) find that the use of assets sales to smooth earnings is less pronounced in countries that permit revaluation of book value of non-current assets than in countries that do not allow the option. Their finding suggests that holding everything else equal, managers prefer accruals management to manipulation of real business activities.

However, the potential costs associated with accruals earnings management can increase dramatically with the cumulative degree of accruals manipulation. As accruals management exceeds certain levels and becomes aggressive, managers face higher risks of auditor scrutiny, regulatory investigations and lawsuits (Dechow, Kothari, \& Watts, 1996; DeFond \& Subramanyam, 1998). Financial reporting problems can have serious consequences. Desai et al. (2006) document reputational penalties to managers of firms announcing earning restatements in terms of high job turnovers and poor subsequent employment of displaced managers. Firms subject to SEC investigations experienced a price decline close to $10 \%$ at the announcements of alleged earnings management (Feroz, Park, \& Patena, 1991; Dechow, Sloan, \& Sweeney, 1996).

In contrast, real earnings management is more subtle and more difficult to detect. In regard to stock repurchases, SEC Rule 10b-18 provides an easy-to-follow safe harbor guideline (Note 1). Under the rule, once a firm publicly announces its repurchase program after board authorization, it is not required to disclose details about the price, timing and amount of individual repurchase transactions (Note 2). As a result, managers enjoy substantial flexibility in the timing and scale of actual repurchases (Stephens \& Weisbach, 1998; Cook, Krigman, \& Leach, 2004) (Note 3). The inherent flexibility and low visibility make open market stock repurchases a potentially convenient device of earnings management for firms that are limited in their ability to manage earnings by 
accruals. For instance, Hribar et al. (2006) document firms manage earnings by buying back their common shares to meet or beat analysts' quarterly EPS forecasts (Note 4). Bens, Nagar and Wong (2003) find that firms repurchase their shares to mitigate the dilution of EPS by stock option exercises.

Therefore, when firms have constraints in their ability to manipulate accruals, the marginal cost of accruals management may exceed that of manipulation of business activities, such as stock repurchases. As real earnings management becomes relatively less costly, firms are likely to substitute real earnings management for accruals management (Demski, 2004; Ewert \& Wagenhofer, 2005). Specifically, firm with constraints in their ability to manipulate accruals are expected to have a higher propensity to manage earnings through stock repurchases.

In fact, Zang (2012) finds that managers switch from accruals manipulation to real earnings management in response to increased litigation risk after the filing of federal class action securities lawsuits against their firms. Cohen et al. (2008) find that the level of accruals earnings management declined after the passage of the Sarbanes-Oxley Act (SOX), whereas the level of real earnings management increased significantly (Note 5). Their findings suggest that after the passage of SOX, firms are likely to have partially switched from accrual earnings management to real earnings management due to increased regulatory scrutiny and litigation risk. Hence we have the following hypothesis.

\section{Firms that have constraints in their ability to manage earnings by inflating accruals have a higher propensity to manage earnings through stock repurchases.}

The current study uses the abnormal net operating assets over sales ratio (AbNOA) as a proxy for constraints on firms' ability to inflate accruals. Barton and Simko (2002) show that net operating assets reflect the cumulative effects of prior accounting choices. Through the articulation between the income statement and balance sheet, previous optimistic accruals adjustments accumulate on the balance sheet and overstate the net operating assets. Since accounting discretion within GAAP is not unlimited, managers' optimistic accounting assumptions in one period reduce their ability to make equally optimistic assumptions in subsequent periods. Therefore, the extent to which net operating assets are overstated proxies the level of constraints managers face in optimistically manipulating the accruals in the current and future periods (Note 6).

\section{Description of Data and Methodology}

\subsection{Data Sources}

The sample consists of quarterly data for U.S. firms that are listed on the NYSE, AMEX and NASDAQ exchanges and have data items required for empirical tests from 1992 to 2009. The sample period starts with 1992 because it is the first year when executive compensation data are available in ExecuComp. The sample ends in 2009 because the calculation of intrinsic values with realized earnings requires 3 years of subsequent earnings. Following Bens, Nagar, and Wong (2002) and Hribar et al. (2006), firms in the banks, utilities and transportation industries are excluded from the sample, since firms in the regulated industries may face constraints in managing earnings via stock repurchases. As in Hribar et al. (2006), large repurchases that account for more than $20 \%$ of a firm's total market value during a quarter are removed from the sample. These large repurchases are likely to be fixed price tender offers, and the current study focuses on only open market repurchases. The sample only includes firm-quarters in which a company's earnings meet or just beat analyst earnings forecasts.

Stock repurchases and other firm-specific financial statement data are obtained from COMPUSTAT Quarterly Industrial and Research files. Monthly stock returns, executive compensation, and analyst earnings forecasts are obtained from CRSP, ExecuComp, and IBES databases, respectively.

\subsection{Expectation Model to Estimate the Normal Level of NOA}

Barton and Simko (2002) show that the level of net operating assets (NOA) reflects the cumulative effect of prior accruals management and thus serves as a measure of firms' accounting flexibility. However, the normal level of net operating assets (NOA) for a firm is likely to be affected by industry and other factors unrelated to earnings management (DeFond, 2002). The current study develops the following expectation model to estimate the normal level of NOA.

$$
\log N_{\text {OA }} A_{i, t}=a_{1}+a_{2} \log \text { Sales }_{i, t}+a_{3} \text { LifeCycle }_{i, t}+a_{4} \text { CapInt }_{i, t-1}+\sum_{j=1}^{4} Q_{j}+\varepsilon_{i, t}
$$

where,

$\log \mathrm{NOA}_{\mathrm{t}}=\log$ of ending net operating assets of quarter $\mathrm{t}$; 


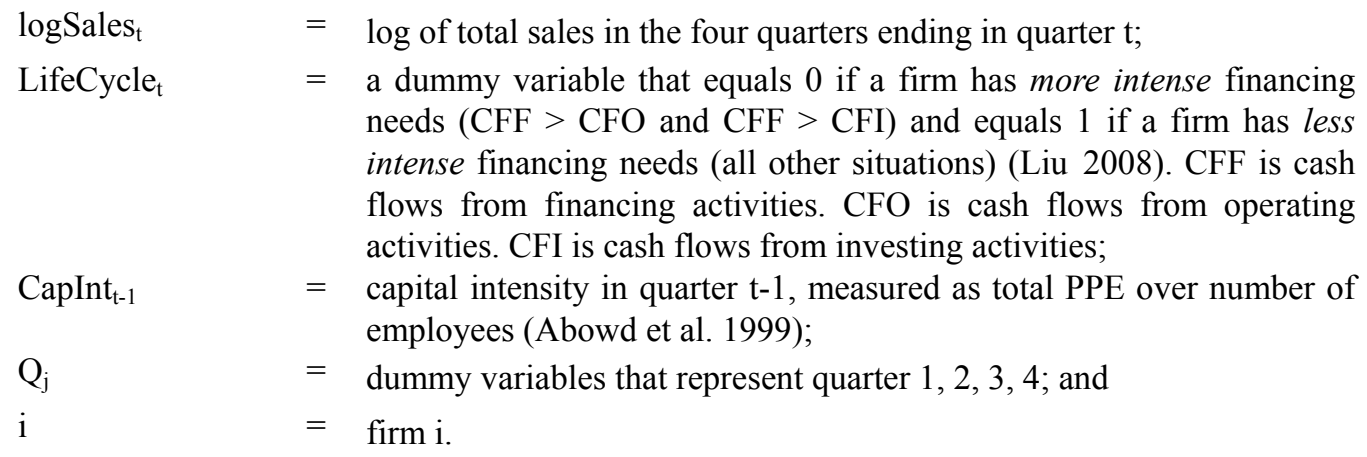

The above equation models the log of net operating assets as a function of log of sales, the firm's life cycle, and capital intensity. Dechow et al. (1998) suggest that the amount of working capital needed in operations is a linear function of sales. LifeCycle is a measure of a firm' life cycle stage developed by Liu (2008) based on the firm's financing intensity. Liu (2008) shows that managerial operating decisions on capital investments differs across growing, mature and declining firms. For a given amount of sales, growing firms tend to make more investments than mature and declining firms, which leads to large positive accruals for growing firms and negative accruals for declining firms. Capital intensity is adopted in the model to account for variations in firms' production input mix in terms of labor and capital (Abowd, Kramarz, \& Marglis, 1999). Dupuy and Grip (2006) demonstrate that the substitution between labor and capital enables firms to generate a given amount of sales with different input factor combinations. Because the model is estimated using quarterly data, dummy variables representing quarters are added to the model to control for potential seasonal effect.

The model is estimated by year and industry to control for variations of operating assets across quarter and industry for all firms in the COMPUSTAT. Abnormal NOA is obtained from the residuals of the expectation model. The estimated abnormal NOA measures the extent to which the balance sheet is overstated and thus serves as a proxy for accounting flexibility.

\subsection{Regression Model for Testing the Hypothesis}

The following logit model tests the hypothesis, which proposes that firms with restricted ability to manage earnings by accruals have a higher propensity to manage earnings through stock repurchases. The dependent variableis a dummy variable, with 1 representing firms engaged in earnings management through stock repurchases and 0 otherwise. To examine firms' decisions about whether to manage earnings by buying back stock, by manipulating operations, or by inflating accruals, the logit model contains three sets of independent variables. The first three variables (AbNOA, AbAccual, and BigAuditor) account for accruals manipulation, the fourth variable (AbProd) controls for manipulation of operations, and the rest nine variables control for factors that affect stock repurchases.

$$
\begin{aligned}
\text { EMRepurchase }_{i, t}=a_{1} & a_{2} \text { AbNOA }_{i, t-1}+a_{3} \text { AbAccruals }_{t-1}+a_{4} \text { BigAuditor }_{t}+a_{5} \text { AbProd }_{i, t} \\
& +a_{6} \text { PE }_{i, t-1}+a_{7} \text { Options }_{i, t-1}+a_{8} P / V_{i, t-1}+a_{9} \text { CashFlow }_{i, t-1, t-4}+a_{10} \text { Debt }_{i, t-1} \\
& +a_{11} \text { DivYield }_{i, t-1}+a_{12} \text { Size }_{i, t-1}+\gamma_{J} \sum_{J=1}^{4} \text { Qtr }_{i, j}+\gamma_{K} \sum_{K=1992}^{2009} \text { Year }_{i, k}+\varepsilon_{i, t}
\end{aligned}
$$

where,

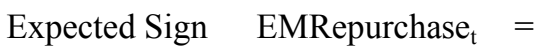

$\begin{array}{ll}+ & \text { AbNOA }_{\mathrm{t}-1}= \\ + & \text { AbAccruals }_{\mathrm{t}-1}= \\ + & \text { BigAuditor }_{\mathrm{t}-1}=\end{array}$

a dummy variable that equals 1 if the firm is assumed to be engaged in earnings management through stock repurchases and 0 otherwise. A firm is assumed to be engaged in earnings management through stock repurchases if it increases its quarterly EPS through stock repurchases to meet or beat analyst earnings forecasts;

abnormal level of net operating assets estimated from model 2 deflated by sales;

abnormal accruals deflated by total assets in the prior period estimated with Jones (1991) model;

a dummy variable that equals 1 if the firm has a big 8 auditor in period $\mathrm{t}$, and 0 otherwise; 


\begin{tabular}{|c|c|c|c|}
\hline - & $\operatorname{AbProd}_{\mathrm{t}-1}$ & $=$ & $\begin{array}{l}\text { abnormal production costs (cost of goods sold plus change in } \\
\text { inventory) divided by prior quarter end total assets. Abnormal } \\
\text { production costs are estimated with the expectation model in } \\
\text { Roychowdhury (2006) (Note } 7 \text { ); }\end{array}$ \\
\hline$?$ & $\mathrm{PE}_{\mathrm{t}-1}$ & $=$ & $\begin{array}{l}\text { stock price at end of prior quarter divided by prior } 12 \text {-month } \\
\text { earnings per share; }\end{array}$ \\
\hline+ & Options $_{\mathrm{t}-1}$ & $=$ & $\begin{array}{l}\text { Log of net worth of total exercisable executive stock options and } \\
\text { stock holdings for the five highest paid executives at the } \\
\text { beginning of the quarter; }\end{array}$ \\
\hline- & $\mathrm{P} / \mathrm{V}_{\mathrm{t}-1}$ & $=$ & $\begin{array}{l}\text { average market value in a quarter divided by estimated intrinsic } \\
\text { value. The intrinsic value is calculated using the using the } \\
\text { residual income model (Note } 8 \text { ). Following D'Mello and Shroff } \\
\text { ( } 2000 \text { ), future realized earnings are used as input to the residual } \\
\text { income based on the assumptions that managers have accurate } \\
\text { foresight of their firms' future performance (Note 9); }\end{array}$ \\
\hline+ & CashFlow $_{\mathrm{t}-1, \mathrm{t}-4}$ & $=$ & $\begin{array}{l}\text { free cash flows (operating cash flows minus capital expenditures } \\
\text { and dividends) over previous four quarters divided by total assets } \\
\text { at the beginning of the quarter; }\end{array}$ \\
\hline- & $\operatorname{Debt}_{\mathrm{t}-1}$ & $=$ & total debt divided by total assets at the beginning of the quarter; \\
\hline+ & DivYield $_{\mathrm{t}-1}$ & $=$ & $\begin{array}{l}\text { dividends per share divided by stock price at the beginning of the } \\
\text { quarter; }\end{array}$ \\
\hline$?$ & Size $_{t-1}$ & $=$ & log of total market value of equity at the beginning of the quarter; \\
\hline & Year & $=$ & calendar year; \\
\hline & $\varepsilon$ & $=$ & error term; and \\
\hline & $\mathrm{i}$ & $=$ & firm i. \\
\hline
\end{tabular}

A firm is classified as engaged in earnings management through stock repurchases if it meets or just beats analyst earnings forecasts and repurchases its stock to increase EPS in the quarter. Meeting or just beating analyst earnings expectations is defined as the earnings surprise equal to 0 or 1 penny. The earnings surprise for a quarter is equal to the IBES actual quarterly EPS minus the analysts' consensus quarterly EPS forecast, both rounded to the nearest penny. The consensus forecast is the median of analysts' most recent quarterly earnings forecasts prior to the earnings announcement for that quarter.

Accounting discretion is proxied by the ratio of abnormal net operating assets over sales (AbNOA). Since high AbNOA implies constraints on firms' ability to inflate accruals, firms with high AbNOAs (AbAccruals) are expected to be more likely to manage earnings through stock repurchases. Abnormal accruals tend to reverse in the subsequent period. The reversal of prior period accruals makes it more difficult to inflate accruals in the current period (Zang, 2012). Previous literature has argued that Big 4 auditors tend to be more experienced, have better audit quality and have more reputation at risk. As a result, firms with Big 4 auditors (BigAuditor) may be under more auditor scrutiny, which deters earnings management through accruals (Becker et al., 1998). Therefore, both AbAccruals and BigAuditor are expected to be positively associated with earnings management through stock repurchases.

Roychowdhury (2006) finds that some firms manipulate their production activities in order to meet earnings targets. The current study adopts the Roychowdhury (2006) model to estimate the abnormal level of production costs (AbProd). The variable AbProd controls for manipulation of operations to manage earnings (Note 10). Two opposing factors affect the association between price to earnings ratio $(\mathrm{PE})$ and the propensity to manage earnings through stock repurchase. On the one hand, high PE firms have more incentives to manage earnings to meet earnings targets (Barth et al., 1999). On the other hand, the prices of high PE firms are less likely to be low relative to the intrinsic value, and stock repurchases are more likely to decrease the EPS of high PE firms (Guay, 2002). The sign of the coefficient for PE depends on the net effect of these two factors. Options should be positively related to the propensity to manage earnings through stock repurchases, because of the following two reasons. First, mangers with high executive stock options have more incentives to manage earnings to maintain stock price (Cheng \& Warfield, 2005). Second, firms tend to buy back stock to cover stock options exercises (Kahle, 2002).

The logit model also controls for a number of factors that affect stock repurchases as documented in prior studies. 
Because managers tend to repurchase more stock when they believe their stock is undervalued (D'Mello \& Shroff, 2000; Dittmar, 2000), P/V is expected to be negatively associated with stock repurchases. CashFlow is expected to have a positive coefficient, because firms with more free cash flows tend to distribute excess cash through stock repurchases (Stephens \& Weisbach, 1998). Debt should be negatively associated with repurchases. The debt level has a two-fold effect on stock repurchases: (1) debt level is negatively related to firms' ability to borrow cash to pay for stock repurchases, and (2) firms may use stock repurchases to increase leverage towards an optimal capital structure (Hovakimian, Opler, \& Titman, 2001) (Note 11). DivYield controls for possible substitution of dividends for stock repurchases as corporate payout (Grullon \& Michaely, 2002). Year accounts for variations in the aggregate levels of stock repurchases over the sample period.

\section{Empirical Test Results}

\subsection{Descriptive Statistics}

Table 1 reports descriptive statistics for the sample of 4,324 firm quarters. The mean level of abnormal operating assets ratio is 0.701 . The average total assets of the sample are $\$ 6,805$ million, much larger than the mean total assets of $\$ 2,171$ million for the whole COMPSTAT. IBES and ExecuComp tend to cover larger and more profitable firms. As a result, the requirement for IBES analyst earnings forecasts and ExecuComp compensation data leads to substantial differences between the sample and the whole COMPUSTAT data. The average amount of cash flows is $\$ 57$ million. The mean debt ratio, dividend yield and PE ratio for the sample are 0.207, 0.011, and 21 .

Table 1. Descriptive statistics

\begin{tabular}{lllllll}
\hline Variables & Mean & $\begin{array}{l}\text { Standard } \\
\text { Deviation }\end{array}$ & $25 \%$ & Median & $75 \%$ & $\mathrm{~N}$ \\
\hline AbNOA & 0.701 & 0.205 & 0.660 & 0.660 & 0.660 & 4,324 \\
AssetsTtl & 6,805 & 29,721 & 370 & 969 & 3,038 & 4,324 \\
CashFlowTtl & 57 & 2831 & -54 & 23 & 148 & 4,324 \\
Debt & 0.207 & 0.161 & 0.057 & 0.199 & 0.322 & 4,324 \\
DivYield & 0.011 & 0.013 & 0.000 & 0.007 & 0.019 & 4,324 \\
OptionsTtl & 209 & 263 & 1 & 3 & 118 & 4,324 \\
PE & 21 & 35 & 13 & 19 & 27 & 4,324 \\
EPS & 0.418 & 0.661 & 0.190 & 0.360 & 0.600 & 4,324 \\
\hline
\end{tabular}

Notes: AbNOA is industry-adjusted net operating assets deflated by total assets at beginning of the quarter. AssetsTtl is total assets at the beginning of the quarter. CashFlowTtl is free cash flows in millions over prior four quarters. Debt is total debt divided by total assets at the beginning of the quarter. DivYield is annual dividends per share divided by stock price at the beginning of the quarter. OptionsTtl is net worth of exercisable stock options for the five highest paid executives in millions. PE is price divided by earnings over the prior 12 months. EPS is quarterly reported earnings per share in dollars. $\mathrm{N}$ refers to the number of observations in the sample.

Table 2 presents Pearson correlations between the major variables. The correlations show a pattern consistent with prior findings. The indicator variable EMRepurchase is significantly positively correlated with AbNOA and CashFlow at four and one percent levels, respectively. It is negatively correlated with $\mathrm{P} / \mathrm{V}$ ratio at the five percent level. The correlations indicate that firms with high Abnormal NOAs, high free cash flows and low P/Vs are more likely to engage in earnings management through stock repurchases. The correlations between the variables are with the range of -0.023 to 0.238 .

\subsection{Empirical Test Results on the Hypothesis}

The hypothesis predicts that firms with low accounting flexibility are more likely to engage in earnings management through stock repurchases, controlling for factors that affects stock repurchases. Table 3 contains test results that support the hypothesis. The key test variable is AbNOA. A significantly positive coefficient for AbNOA would indicate that firms with highly inflated accruals is more likely to use stock repurchases as a means of managing earnings to meet analysts' forecasts. The coefficient of AbNOA is 0.51 , significant at the one percent level (two-tailed), supporting the prediction that firms with constraints in their ability to manipulate accruals have a higher propensity to manage earnings through stock repurchases. Among the control variables, $\mathrm{PE}$ and Size are negative at two and five significance percent levels, respectively. CashFlow and DivYield are 
Table 2. Pearson correlations between major variables in the study

\begin{tabular}{|c|c|c|c|c|c|}
\hline & EMRepurchase & AbNOA & $\mathrm{P} / \mathrm{V}$ & $\mathrm{PE}$ & Options \\
\hline \multicolumn{6}{|c|}{ EMRepurchase } \\
\hline \multirow[t]{2}{*}{ AbNOA } & 0.023 & & & & \\
\hline & .04 & & & & \\
\hline \multirow[t]{2}{*}{$\mathrm{P} / \mathrm{V}$} & -0.021 & 0.034 & & & \\
\hline & .05 & $(<0.01)$ & & & \\
\hline \multirow[t]{2}{*}{ PE } & -0.015 & 0.013 & 0.119 & & \\
\hline & 0.13 & 0.20 & $(<0.01)$ & & \\
\hline \multirow[t]{2}{*}{ Options } & -0.007 & 0.091 & 0.077 & 0.108 & \\
\hline & 0.49 & $(<0.01)$ & $(<0.01)$ & $(<0.01)$ & \\
\hline \multirow[t]{2}{*}{ CashFlow } & 0.028 & -0.017 & -0.023 & 0.057 & 0.238 \\
\hline & 0.01 & 0.08 & 0.02 & $(<0.01)$ & $(<0.01)$ \\
\hline
\end{tabular}

Notes: Correlation coefficients are presented above the p-value in brackets. Variable definitions: EMRe purchase is a dummy variable which equals 1 if a firm is identified to be engaged in earnings management through stock repurchases and 0 otherwise. AbNOA is industry-adjusted net operating assets deflated by total assets at beginning of the quarter. $\mathrm{P} / \mathrm{V}$ is market value of equity divided by the intrinsic value calculated with the residual income model. PE is price divided by earnings over the prior 12 months. Options is the log of net worth of exercisable executive stock options for the five highest paid executives. CashFlow is free cash flows over prior 4 quarters divided by total assets at beginning of the quarter.

Table 3. Logit regression results on the effect of accounting flexibility on propensity of earnings management through stock repurchases

\begin{tabular}{ccc}
\hline Variables & Coefficient Estimates & P-Value \\
\hline Intercept & -1.21 & 0.09 \\
AbNOA & $\mathbf{0 . 5 1}$ & $<\mathbf{0 . 0 1}$ \\
AbAccruals & -0.09 & 0.72 \\
BigAuditor & -0.14 & 0.75 \\
AbProd & -0.13 & 0.44 \\
PE & -0.01 & 0.02 \\
Options & -0.04 & 0.45 \\
P/V & -0.02 & 0.22 \\
CashFlow & 0.96 & 0.08 \\
Debt & -0.93 & 0.14 \\
DivYield & 18.65 & $<0.01$ \\
Size & -0.15 & 0.05 \\
Log Likelihood of the Model & & 276 \\
No. of Observations & & 4,324 \\
\hline
\end{tabular}

Variable definitions: EMRepurchase is the dependent variable of the logit regression model. It is a dummy variable which equals 1 if the firm is identified to be engaged in earnings management through stock repurchases and 0 otherwise. A firm is inferred to be engaged in earnings management through stock repurchases if it meets or just beats analyst earnings forecasts and would have missed analyst forecasts without doing stock repurchases. AbNOA is industry-adjusted net operating assets deflated by total assets at beginning of the quarter. AbAccruals is abnormal accruals estimated with the Jones model. BigAuditor is dummy variable, equal to 1 if the firm has a big 4 auditor, equal to 0 otherwise. $\mathrm{PE}$ is price divided by earnings over the prior 12 months. Options is net worth of exercisable executive stock options for the five highest paid executives divided by total market value. $\mathrm{P} / \mathrm{V}$ is average market value in a quarter divided by estimated intrinsic value estimated with the residual income model. CashFlow is free cash flows over prior four quarters(operating cash flows minus capital expenditures and dividends) divided by total assets at the beginning of the quarter. Debt is total debt divided by total assets at the beginning of the quarter. DivYield is annual dividends per share divided by stock price at the beginning of the quarter. Size is log of total market value of equity at the beginning of the quarter. The regression controls for quarter and year effect. For simplicity, estimated coefficients for quarter and year are not reported in the table. 
significantly positive at eight and one percent levels, respectively. The results indicate that firms that are large, have high PE ratios, or low cash flows and dividend yields are less likely to manage earnings through stock repurchases.

\section{Conclusions}

The current study shows that firms with constraints in their ability to inflate accruals have a higher propensity to manage earnings through stock repurchases. The result suggests that accruals management and real earnings management serve as alternative means of earnings management and firms could be induced to the more costly real earnings management under certain conditions. The findings of the study have implications for future research Prior research examines the magnitude of discretionary accruals to determine the existence of earnings management. Abnormally high discretionary accruals imply earnings management, whereas normal levels of discretionary accruals are regarded as evidence of no earnings management. However, firms could be managing earnings by altering the underlying business activities instead of manipulating accruals. Therefore, it is not sufficient to examine only discretionary accruals to determine whether a firm is engaged in earnings management. Researchers need to examine both the levels of discretionary accruals and real business activities to determine whether a firm is engaged in earnings management.

\section{References}

Abowd, J., Kramarz, F., \& Marglis, D. (1999). High wages workers and high wage firms. Econometrica, 67, 251-333. http://dx.doi.org/10.1111/1468-0262.00020

Baber, W. R., \& Fairfield, P. M. (1991). The effect of concern about reported income on discretionary spending decisions: The case of research and development. The Accounting Review, 66, 818-829.

Barth, M., Elliott, E., \& Finn, M. (1999). Market rewards associated with patterns of increasing earnings. Journal of Accounting Research, 37, 387-414. http://dx.doi.org/10.2307/2491414

Barton, J., \& Simko, P. J. (2002). The balance sheet as an earnings management constraint. The Accounting Review, 77, 1-27. http://dx.doi.org/10.2308/accr.2002.77.s-1.1

Becker, C., DeFond, M., Jiambalvo, J., \& Subramanyam, K. (1998). The effect of audit quality on earnings management. Contemporary Accounting Research, 15, 1-24. http://dx.doi.org/10.1111/j.1911-3846.1998.tb00547.x

Bens, D. A., Nagar, V., \& Wong, M. H. F. (2002). Real investment implications of employee stock option exercises. Journal of Accounting Research, 40, 359-393. http://dx.doi.org/10.1111/1475-679X.00052

Bens, D. A., Nagar, V., \& Wong, M. H. F. (2003). Employee stock options, EPS dilution, and stock repurchase. Journal of Accounting and Economics, 36, 51-90. http://dx.doi.org/10.1016/j.jacceco.2003.10.006

Black, E. L., Sellers, K. F., \& Manly, T. S. (1998). Earnings management using asset sales: An international study of countries allowing noncurrent asset revaluation. Journal of Business Finance and Accounting, 25, 1287-1319. http://dx.doi.org/10.1111/1468-5957.00238

Bushee, B. (1998). The influence of institutional investors on myopic R\&D investment behavior. The Accounting Review, 73, 305-333.

Cheng, Q., \& Warfield, T. D. (2005). Equity incentives and earnings management. The Accounting Review, 80, 441-476. http://dx.doi.org/10.2308/accr.2005.80.2.441

Cohen, D. A., Dey, A., \& Lys, T. Z. (2008). Real and accrual-based earnings management in the pre and post-Sarbanes-Oxley periods. The Accounting Review, 83, 757-787. http://dx.doi.org/10.2308/accr.2008.83.3.757

Cook, D., Krigman, L., \& Leach, J. (2004). On the timing and execution of open market repurchases. The Review of Financial Studies, 17, 463-498. http://dx.doi.org/10.1093/rfs/hhg028

Dechow, P., Sloan, R. G., \& Sweeney, A. P. (1996). Causes and consequences of earnings manipulation: An analysis of firms subject to enforcement actions by the SEC. Contemporary Accounting Research, 13, 1-36. http://dx.doi.org/10.1111/j.1911-3846.1996.tb00489.x

Dechow, P., Kothari, S. P., \& Watts, R. L. (1998). The relation between earnings and cash flows. Journal of Accounting and Economics, 25, 133-168. http://dx.doi.org/10.1016/S0165-4101(98)00020-2

DeFond, M. L. (2002). Discussion of the balance sheet as an earnings management constraint. The Accounting Review, 77, 29-33. http://dx.doi.org/10.2308/accr.2002.77.s-1.29 
DeFond, M. L., \& Subramanyam, K. (1998). Auditor changes and discretionary accruals. Journal of Accounting and Economics, 35-67. http://dx.doi.org/10.1016/S0165-4101(98)00018-4

Demski, J. (2004). Endogenous expectations. The Accounting Review, 79, 519-539. http://dx.doi.org/10.2308/accr.2004.79.2.519

Desai, H., Hogan, C. E., \& Wilkins, M. S. (2006). The reputational penalty for aggressive accounting: earnings restatements and management turnover. The Accounting Review, 81, 83-112. http://dx.doi.org/10.2308/accr.2006.81.1.83

Dittmar, A. K. (2000). Why do firms repurchase stock? Journal of Business, 73, 331-355. http://dx.doi.org/10.1086/209646

D’Mello, R., \& Shroff, P. (2000). Equity undervaluation and decisions related to repurchase tender offers: An empirical investigation. Journal of Finance, 55, 2399-2424. http://dx.doi.org/10.1111/0022-1082.00292

Dupuy, A., \& Grip, A. D. (2006). Elasticity of substitution and productivity, capital and skill intensity differences across firms. Economics Letters, 90, 340-347. http://dx.doi.org/10.1016/j.econlet.2005.08.025

Ewert, R., \& Wagenhofer, A. (2005). Economic effects of tightening accounting standards to restrict earnings management. The Accounting Review, 80, 1101-1124. http://dx.doi.org/10.2308/accr.2005.80.4.1101

Feroz, E. H., Park, K., \& Pastena, V. S. (1991). The financial and market effects of the SEC's accounting and auditing enforcement releases. Journal of Accounting Research, 29, 107-142. http://dx.doi.org/10.2307/2491006

Frankel, R., \& Lee, C. (1998). Accounting valuation, market expectations, and cross-sectional stock returns. Journal of Accounting and Economics, 25, 283-319. http://dx.doi.org/10.1016/S0165-4101(98)00026-3

Grullon, G., \& Michaely, R. (2002). Dividends, share repurchases, and the substitution hypothesis. Journal of Finance, 57, 1649-1684. http://dx.doi.org/10.1111/1540-6261.00474

Guay, W. (2002). Discussion of real investment implications of stock option exercises. Journal of Accounting Research, 40, 395-406. http://dx.doi.org/10.1111/1475-679X.00053

Healy, P. M., \& Wahlen, J. M. (1999). A review of the earnings management literature and its implications for standard setting. Accounting Horizons, 13, 365-383. http://dx.doi.org/10.2308/acch.1999.13.4.365

Hirshleifer, D., Hou, K., Teoh, S. H., \& Zhang, Y. (2004). Do investors overvalue firms with bloated balance sheets? Journal of Accounting \& Economics, 38, 297-331. http://dx.doi.org/10.1016/j.jacceco.2004.10.002

Hovakimian, A., Opler, T., \& Titman, S. (2001). The debt-equity choice. Journal of Financial and Quantitative Analysis, 36, 1-24. http://dx.doi.org/10.2307/2676195

Hribar, P., Jenkins, N. T., \& Johnson, W. B. (2006). Stock repurchases as an earnings management device. Journal of Accounting and Economics, 41, 3-27. http://dx.doi.org/10.1016/j.jacceco.2005.10.002

Jones, J. (1991). Earnings management during important relieve investigations. Journal of Accounting Research, 29, 193-228. http://dx.doi.org/10.2307/2491047

Kahle, K. M. (2002). When a buyback isn't a buyback: open market repurchases and employee options. Journal of Financial Economics, 63, 235-261. http://dx.doi.org/10.1016/S0304-405X(01)00095-2

Liu, M. (2008). Accruals and managerial operating decisions over the firm life cycle. Working paper, the Pennsylvania State University.

Penman, S., \& Sougiannis, T. (1998). A comparison of dividend, cash flow, and earnings approaches to equity valuation. Contemporary Accounting Research, 15, 343-383. http://dx.doi.org/10.1111/j.1911-3846.1998.tb00564.x

Roychowdhury, S. (2006). Earnings management through real activities manipulation. Journal of Accounting and Economics, 42, 335-370. http://dx.doi.org/10.1016/j.jacceco.2006.01.002

Schipper, K. (1989). Commentary on earnings management. Accounting Horizons, 3, 91-102.

Stephens, C. P., \& Weisbach, M. S. (1998). Actual share reacquisitions in open-market repurchase programs. Journal of Finance, 53, 313-333. http://dx.doi.org/10.1111/0022-1082.115194

Taylor, G. K, \& Xu, R. Z. (2012). Cost of earnings management through stock repurchases. Working paper, University of Alabama.

Wang, S., \& D'Souza, J. (2006). Earnings management: The effect of accounting flexibility on R\&D investment 
choices. Working paper, Cornel University.

Zang, A. Y. (2012). Evidence on the trade-off between real activities manipulation and accrual-based earnings management. The Accounting Review, 87(2), 675-703.

\section{Notes}

Note 1. Rule 10b-18, which was adopted in 1982, provides a "safe harbor" from liability for manipulation of stock price under Sections 9(a) (2), 10(b), and Rule 10b-5 of the Securities Exchange Act of 1934, when an issuer or its affiliated purchaser bids for or purchases shares of the issuer's common stock in accordance with the Rule 10b-18's manner, timing, price, and volume conditions. On November 10, 2003 subsequent to the Sarbanes-Oxley Act, the SEC simplified the safe harbor provisions in Rule 10b-18 in light of market developments since the rule's adoption. Among other things, the amendments extend the safe harbor to certain after-hours repurchases and clarify the scope of the safe harbor with regard to mergers, acquisitions, and similar transactions. (http://www.sec.gov/divisions/marketreg/r10b18faq0504.htm).

Note 2. Firms disclose only the total dollar amount of stock repurchases in their quarterly and annual reports.

Note 3. The large dispersions in firms' actual repurchases after repurchase announcements illustrate firms' flexibility in adjusting the timing and scale of their repurchases. An average firm buys back $77 \%$ of target shares within three years. $10 \%$ of firms buy back less than $5 \%, 57 \%$ of firms repurchase all target shares, and $30 \%$ of firms even repurchase twice as many shares originally announced (Stephens \& Weisbach, 1998).

Note 4. Hribar et al. (2006) show that repurchases reduce the number of common shares outstanding, and at the same time, consume capital that could have been used to generate income. Therefore, stock repurchases increase EPS only when the earnings price ratio is larger than the foregone rate of return on cash paid for the repurchase.

Note 5. Cohen et al. (2008) examine various forms of real earnings management activities, including accelerating sales through price discounts, reporting lower cost of goods sold by increasing production, decreasing advertising, R\&D, and SG\&A expenses.

Note 6. Prior studies use NOA as a proxy for constraints on accruals manipulation in their empirical analysis. Specifically, Wang and D'Souza (2006) find that firms with high NOA are more likely to cut R\&D expenditures to avoid earnings decrease. Hirshleifer, Hou, Teoh, and Zhang (2004) suggest that net operating assets represent the difference between cumulative net operating income (accounting value-added) and cumulative free cash flow (cash value-added) and measure the extent to which past earnings have been over-optimistic compared to the underlying operations. They find that the level of net operating assets is negatively related to future returns.

Note 7. Roychowdhury (2006) develops a model to estimate the normal levels of production in order to identify firms that manage earnings by manipulating their production activities. The model specifies the production level as a function of current sales and changes in current and last period sales, i.e.,

$$
\text { PROD }_{i, t}=a_{1} \frac{1}{T A_{i, t-1}}+a_{2} \frac{\text { Sales }_{i, t}}{T A_{i, t-1}}+a_{3} \frac{\Delta \text { Sales }_{i, t}}{T A_{i, t-1}}+a_{4} \frac{\Delta \text { Sales }_{i, t-1}}{T A_{i, t-1}}+\varepsilon_{i, t} .
$$

Note 8. Various prior studies derive (Frankel \& Lee,1998; Penman \& Sougiannis, 1998) firms' intrinsic value using the residual income model. Frankel and Lee (1998) find that the intrinsic value estimated using the residual income model is highly correlated with contemporaneous stock price and that the ratio of intrinsic value over market value could predict long term cross-sectional stock returns. Penman and Sougiannis (1998) show that the residual income model performs better than discounted cash flows and discounted dividend models in estimating firm value.

Note 9. Using realized earnings is consistent with the idea that managers have private information on firms' future performance that is not available to analysts and other outside investors and that mangers assess their firms' intrinsic value using their private information. The findings of D'Mello and Shroff (2000) support the assumption that managers have precise private information on firms' future performance. They also show that their results hold after relaxing the assumption on managers' perfect foresight on future operating performance. Penman and Sougiannis (1998) use a similar approach to calculate intrinsic value.

Note 10. Prior studies (Baber \& Fairfield, 1991) also find evidence that firms cut R\&D expenditures to boost earnings. Since the majority of the sample firms do not have quarter data on R\&D expenses, the current study does not control for R\&D expenditures in the logit model.

Note 11. Capital structure refers to the mixture of equity and debt that comprises a firm's total capital. 


\section{Copyrights}

Copyright for this article is retained by the authors, with first publication rights granted to the journal.

This is an open-access article distributed under the terms and conditions of the Creative Commons Attribution license (http://creativecommons.org/licenses/by/3.0/). 